\section{Translation of Addressing Terms in The Novel This Earth of Mankind}

\author{
Ardik Ardianto \\ Department of Languages and Literatures \\ Universitas Gadjah Mada \\ ardikardianto@gmail.com
}

\begin{abstract}
This paper is an attempt to approach the translational stylistics, aiming at identifying the equivalence and translation procedures used in translating the Toer's authorial style from the Indonesian language to the English language in the novel This Earth of Mankind. A translational stylistics model proposed by Malmkjær was used to contrast the target text (TT) and the source text (ST), primarily focusing on the stylistic shift. Further, as to the model of translation procedures, it specifically employed Vinay and Darbelnet's methodology for translation. Data used in this study were addressing terms found in two novels, the Indonesian novel Bumi Manusia and its translation This Earth of Mankind. The rigorous analysis demonstrated how the translation of addressing terms involved a wide range of aspects, such as sociocultural and historical values (including social identity and social strata) and power and solidarity relation. Therefore, it raised a number of noteworthy translation issues, i.e., its equivalence, stylistic shift, and translator's strategies. Through the increasing awareness of 'cultural turn' in translation studies, the concept of equivalence is supposedly perceived not as an absolute assessment but as a mediating attempt to accommodate and transpose the inferred or perceived meaning from the ST to the TT as much as possible. However, the findings are not set out to appraise the translator's ethical attitude, considering the limited data used in this study and numerous factors that are not yet taken into account, e.g. the power play of the translation industry, and culture-mediating agenda in the receiving culture.
\end{abstract}

Keywords: addressing terms, stylistic shift, translational stylistics

\title{
INTRODUCTION
}

Translating addressing terms is quite challenging in the current trend of translation studies, especially since the rise of cultural turns (Bassnett \& Levere, 1990, p. 11) giving more dominant concern on to what extent the translation should accommodate varied sociocultural issues, i.e., how the equivalence is rather supposedly perceived as a mediating attempt to bridge sociocultural values in both source and target texts, to what extent such equivalence is achieved, how translation shift occurs in both texts, to name a few. This particularly leads to the reformulation of what is previously defined as equivalence. At the early to late twentieth century, what is meant by equivalence in translation studies loosely dealt with two main factors, i.e., strictly linguistic and extra-linguistic (Baker, 2018, p. 16) and therefore mostly created dyadic types of equivalence, that are formal and dynamic (Nida, 1964a, p. 159), semantic and communicative (Newmark, 1988, pp. 5-7), or meaning and message. Although, in later development (in the case of Baker's definition, for example), equivalence starts to receive a wide range of categories depending on which perspective it is grounded. To this regard, therefore, Baker (2018) categorized equivalence into several layers .

To some extent, however, such equivalence types could not yet somehow address sociocultural issues in general and addressing terms in specific. To date, translating addressing terms is mostly approached by means of mere linguistic aspects and neglects otherwise pivotal ones, e.g., sociocultural values, stylistic values, and power solidarity relation. In fact, addressing terms are words or phrases used for addressing (Braun, 1988, p. 7) that profoundly relate to both language and cultural systems and thus pose considerable difficulties for translators so as to transfer them from source text to target text (Lotfollahi \& Dabbaghi, 2012). The difficulties might be of difference in kinship and social terms (Yang, 2010), in sociocultural and pragmatic implications ( $\mathrm{Ngo}, 2006$ ), and honorific terms (Shehab, 2005). These such difficulties seem plausible for addressing terms are dependent upon and highly rely on social identity and status, honor and politeness, and power and solidarity relation (Yang, 2010; Taavitsainen, Jucker, \& Jucker, 2003; Brown \& Gilman, 1960). 
The translation of addressing terms has been investigated by many researchers worldwide. Lotfollahi and Dabbaghi (2012) investigated the translation of English addressing terms into Persian in three short stories. They used two translation models, i.e., Vinay and Darbelnet's and Newmark's model, to identify the procedures used by the translator in translating the texts. The findings of their study indicated that due to distinct addressing terms between English and Persian, translators tended to use a wide range of strategies, such as deletion, addition, cultural equivalence, and transcription. Regardless, the most frequently used strategy was the literal translation, which might lead to a loss in meaning. Furthermore, attempting to scrutinize English and Chinese addressing terms by means of cultural aspects and to formulate suitable translation methods of which, Yang (2010) pointed out that there were two underlying factors as to why translating Chinese addressing terms into English is a rather difficult task, namely difference in kindship system and difference in social terms.

Apart from the aforementioned researches, addressing terms in the Indonesian language has also been of major concern in translation research. Fauliyah (2012) discussed the categorization of addressing terms as well as the strategies used in translating the Indonesian film subtitle. She discovered that the most common addressing terms were in the form of pronouns, while the most frequently preferred strategy was general words. She concluded that Indonesian addressing terms were often translated into more and general English addressing terms so as to ease and provide a better understanding for the target readers. In another study, Fauziah (2014) elaborated that addressing terms were mainly used to indicate power and solidarity relation among collocutors. Since they significantly relate to the context of the situation and pragmatic aspects, there were three patterns used by the translator in translating addressing terms, i.e., literal translation, original terms (loan translation), and adaptation (free translation). She concluded that there was a fidelity ambivalence demonstrated by the translator as he tended to be inconsistent in selecting either source-based or target-based translation and failed to grasp the contextual and cultural gap among the addressing terms.

Despite having considered a sociocultural variable in analyzing addressing terms, none of the researches previously mentioned approach the translation of addressing terms through a stylistic viewpoint. In fact, in my argument, there are two crucial points regarding the translation of addressing terms. First, beside dependent upon sociocultural aspects, addressing terms are supposedly approached by means of translational stylistics, in that they greatly correlate with how they are expressed in the source text so that the influence of which upon the translator's 'creative transposition' can be assessed. Only in this way, the analysis of to what extent the translation equivalence can be fully achieved is possible. Second, the analysis of translation equivalence should include the theory of dynamic reading or close-reading in literary works, bearing in mind that the concept of equivalence hinges on subjective or personal judgment-in other words, on how extensive and comprehensive the reader/in this case translator could interpret the perceived or inferred meaning.

Therefore, this paper strives to encompass not only the sociocultural aspects but also stylistic values embodied in addressing terms. It aims at analyzing the equivalence and stylistic shift of addressing terms by focusing on power and solidarity relation reflected in two novels, Bumi Manusia and its translation This Earth of Mankind. Specifically, through this paper, I argue that there are myriads of rationales, one of which is stylistic consideration, for a translator to deliberately prefer a certain linguistic or stylistic choice to translate addressing terms in various ways. Just because using a wide range of translation variations for the same addressing term, it does not mean that the translator is inconsistent. It is seemingly of banality for Fauziah (2014) to give judgment upon the translator's consistency solely based on his preference without considering otherwise factors.

This study is naturalistic empirical (Williams \& Chesterman, 2002, pp. 62-63) highlighting the translation of addressing terms by means of translational stylistic approach (Malmkjær, 2004). This approach was used to investigate to what extent the equivalence as well as the stylistic shift of addressing terms in the source text were realized in the target text. The data used in this study merely covered Indonesian addressing terms in Toer's novel Bumi Manusia and its translation This Earth of Mankind. The addressing terms were scrutinized based on two main points, namely the representation of power and solidarity relation (Brown \& Gilman, 1960) to figure out its equivalence and the translation procedures used by the translator in translating them. The model used was Vinay and Darbelnet's methodology for translation (2004). The data analysis was carried out in these 
following phases: 1) identifying and categorizing the representation of T/V status (power and solidarity relation) of each addressing term in the source text; 2 ) identifying and categorizing the equivalence of the T/V status gained in the first phase; and last 3) analyzing the stylistic shift of addressing terms in both texts by comparing the stylistic influence in each text.

\section{FINDINGS AND DISCUSSION}

In this section, the analysis is elaborated into three parts: the first part explores the representation of T/V status of the addressing terms in the source text; the second part reviews the equivalence of T/V status through the analysis of translation procedures; and the third part investigates the stylistic shift of the addressing terms.

\section{The Representation of Power and Solidarity Relation}

Prior to the in-depth analysis of each addressing terms found in the novel Bumi Manusia, let me present the overview of the representation of power and solidarity relation as follows:

Table 1. The Overview of Power and Solidarity Representation

\begin{tabular}{|c|c|c|c|c|}
\hline \multicolumn{5}{|c|}{ The Representation of Power dan Solidarity } \\
\hline No. & Page & Data & $\begin{array}{c}\text { T/V } \\
\text { Status }\end{array}$ & Function \\
\hline 1 & 2 & Tuan-tuan guru (ToHC) & V & $\begin{array}{l}\text { Tone: Formal, } \\
\text { respecting }\end{array}$ \\
\hline 2 & 2 & Tuan direktur (ToHC) & V & $\begin{array}{l}\text { Tone: Formal, } \\
\text { respecting }\end{array}$ \\
\hline 3 & 8 & Tuanmuda Minke (ToHFN) & $\mathrm{V}(+\mathrm{T})$ & $\begin{array}{l}\text { Tone: Casual, } \\
\text { respecting }\end{array}$ \\
\hline 4 & 19 & Tuan? (ToH) & $\mathrm{V}(+\mathrm{T})$ & $\begin{array}{l}\text { Tone: Formal, } \\
\text { respecting }\end{array}$ \\
\hline 5 & 24 & Tuan Herman Mellema (ToHFN) & V & $\begin{array}{l}\text { Tone: Formal, } \\
\text { respecting }\end{array}$ \\
\hline 6 & 45 & $\begin{array}{l}\text { Tuanmuda ini tamuku, tamu Noni } \\
\text { Annelies }(\mathrm{ToH})\end{array}$ & $\mathrm{V}$ & $\begin{array}{l}\text { Tone: Formal, } \\
\text { respecting }\end{array}$ \\
\hline 7 & 81 & $\begin{array}{l}\text { Tuan-tuan Totok dan Peranakan } \\
\text { (ToH) }\end{array}$ & V & $\begin{array}{l}\text { Tone: Formal, } \\
\text { respecting }\end{array}$ \\
\hline 8 & 82 & $\begin{array}{c}\text { Tuan Administratur, Tuan Besar } \\
\text { Kuasa }(\mathrm{ToHC})\end{array}$ & V & $\begin{array}{l}\text { Tone: Formal, } \\
\text { respecting }\end{array}$ \\
\hline 9 & 125 & Tuan Raden Mas Minke (ToHFN) & $\mathrm{V}$ & $\begin{array}{l}\text { Tone: Formal, } \\
\text { respecting }\end{array}$ \\
\hline 10 & 135 & Tuan Residen Surabaya (ToHC) & V & $\begin{array}{l}\text { Tone: Formal, } \\
\text { respecting }\end{array}$ \\
\hline
\end{tabular}

All the Indonesian addressing terms, which in this case are the variants of Tuan, represented the power (vos) status between collocutors. Despite sharing the same power status, not all the variants of Tuan shared the equal context of the situation. There were addressing terms used in the asymmetrical and nonreciprocal relation, indicating distinct social strata (superior-inferior), such as in Tuan-tuan guru (1), Tuan direktur (2), Tuan Herman Mellema (5), Tuanmuda (6), Tuan-tuan Totok dan Peranakan (7), Tuan Administratur, Tuan Besar Kuasa (8), Tuan Raden Mas (9), and Tuan Residen (10). The rest addressing terms were used in the symmetrical and reciprocal relation, indicating that the collocutors were of similar or same social strata (middle-high), such as in Tuanmuda Minke (3) and Tuan? (4). All addressing terms with the asymmetrical relation always involved a formal situation and were used to highly respect and praise the superior collocutor. Meanwhile, those with the symmetrical one can vary in terms of the situation involved, either in a casual or formal situation, and used to signal the politeness between collocutors. The politeness here also infers that the collocutors demonstrated the sense of solidarity between one another.

Interestingly, since the setting of the novel was at the late nineteenth and early twentieth century, the addressing term of Tuan along with its variants were widely used by the majority of 
the population in Indonesia (otherwise known as Dutch Indies at that time) regardless the identity, including Natives, Indo-Europeans, or Pure Europeans. To date, this addressing term remains to be used in spite of undergoing such meaning shift (narrowing) and is thus limitedly used in particular situations, for instance, to address employers or respectful people (The Great Indonesian Dictionary, hereinafter abbreviated as GID, p. 1752). It was considered an honorific term or title of honorific $(\mathrm{ToH})$ that could flexibly merge with other titles, such as the title of carrier (Toc) as in guru (1), direktur (2), administratur (8), and residen (10), front or full name as in Minke (3) and Herman Mellema (5), or even with another honorific (Javanese feudal) term as in Raden Mas Minke (9).

If the collocutors were of different social strata, the superior demanded $V$ from the inferior and used $T$ to them and vice versa (the inferior received $T$ and were obliged to use $V$ ). In the context of the use of Tuan in this novel, the superior-inferior relation was illustrated by Minke's teachers and the school director to all the students, Herman Mellema to Minke, Nyai Ontosoroh to Darsam, all Pure-Europeans and Indo-Europeans to common Natives, Mr. Administrator to Sastrotomo, Minke to the Police agent, and Mr. Resident of Surabaya to the common Natives. Besides indicating the power relation, the addressing term of Tuan could also represent the solidarity relation, involving collocutors with the same or equal social strata whether they are in the same high social status or the same middle social status. They tended to use this addressing term either to signal egalitarianism, to demonstrate politeness, or to develop intimacy by enacting what Brown and Gilman (1960) called 'mutual T or V'. Only two out of ten in the data were illustrated this 'mutual $V^{\prime}$ ' (solidarity relation), i.e., Mrs. Télinga to Minke (3) and Nyai Ontosoroh to Minke (4). In order to illustrate these power and solidarity relations, the following figure is presented:

Figure 1. The Map of $\mathrm{T} / \mathrm{V}$ relations



Note:

$\mathrm{V}=$ superior addressing

$\mathrm{T}=$ inferior addressing

$\mathrm{T} / \mathrm{V}=$ mutual solidarity

\section{The Equivalence of Power Solidarity Relation}

After identifying the T/V status of each addressing term, it is important to present the following table so as to figure out the distribution of translation procedures used by the translator.

Table 2. The Distribution of Translation Procedures

\begin{tabular}{lllll}
\hline No. & \multicolumn{1}{c}{ Page } & \multicolumn{1}{c}{ ST } & \multicolumn{1}{c}{ TT } & \multicolumn{1}{c}{ Procedure } \\
\hline 1. & BM-2/TEM16 & Tuan-tuan guru & Your teachers & Literal \\
2. & BM-2/TEM-16 & Tuan Direktur & The director & Literal \\
3. & BM-8/TEM-21 & Tuanmuda Minke & Master Minke! & Literal \\
4. & BM-19/TEM-29 & Tuan? & Sir? & Literal \\
5. & BM-24/TEM-33 & Tuan Herman Mellema & Mr. Herman Mellema & Literal \\
\hline
\end{tabular}




\begin{tabular}{|c|c|c|c|c|}
\hline 6. & BM-45/TEM-50 & $\begin{array}{l}\text { Tuanmuda ini tamuku, } \\
\text { tamu Noni Annelies }\end{array}$ & $\begin{array}{l}\text { The young master is my } \\
\text { guest, is Miss Annelies's } \\
\text { guest }\end{array}$ & Literal \\
\hline 7. & BM-81/TEM-79 & $\begin{array}{l}\text { Tuan-tuan Totok dan } \\
\text { Peranakan akan } \\
\text { memberi tabik }\end{array}$ & $\begin{array}{l}\text { The Pure and Mixed- } \\
\text { Blood tuans would } \\
\text { greet him }\end{array}$ & Calque \\
\hline 8. & BM-82/TEM-80 & $\begin{array}{l}\text { Tuan Administratur, } \\
\text { Tuan Besar Kuasa }\end{array}$ & $\begin{array}{l}\text { the Tuan Besar Kuasa, } \\
\text { the "Great, Powerful } \\
\text { Tuan," to come to the } \\
\text { house. }\end{array}$ & $\begin{array}{l}\text { Borrowing, } \\
\text { Calque }\end{array}$ \\
\hline 9. & $\begin{array}{l}\text { BM-125/TEM- } \\
116\end{array}$ & $\begin{array}{l}\text { "Tak ada yang bisa } \\
\text { menyangkal, Tuan } \\
\text { Raden Mas Minke" }\end{array}$ & $\begin{array}{l}\text { "No one can deny that, } \\
\text { Tuan Raden Mas } \\
\text { Minke" }\end{array}$ & Borrowing \\
\hline 10. & $\begin{array}{l}\text { BM-135/TEM- } \\
125\end{array}$ & $\begin{array}{l}\text { Tuan Residen } \\
\text { Surabaya }\end{array}$ & $\begin{array}{l}\text { Mr. Resident of } \\
\text { Surabaya }\end{array}$ & Literal \\
\hline
\end{tabular}

Based on the distribution table above, it can be seen that the most frequently used procedure was the literal translation (70\% of the total percentage), followed by calque (10\%), borrowing (10\%), and combination of borrowing and calque (10\%). Loosely, it indicates that the translator tended to find the equivalence by literally translate the addressing terms into English directly, which to some degree might lead to a loss in contextual meaning (Lotfollahi \& Dabbaghi, 2012). It does not, however, necessarily mean that all of the addressing terms which had been translated by using literal translation did not achieve equivalence. As mentioned earlier in the initial part of this paper, whether or not the translation is considered equal (thus achieving equivalence) is highly dependent upon the reader's capability in grasping the inferred or perceived meaning in both source text and target text. Hence, what is considered equal by a reader might be less equal by another, depending on how extensive, comprehensive, and critical reading he can manage. Even, the inferred or perceived meaning underlying the equivalence concept, according to Boase-Beier (2014), implies two aspects: 1) meaning does not exist or is not encoded in the text and ergo cannot be decoded as the way many might think of; instead, it can only be reconstructed and the process of reconstructing the perceived meaning per se highly relies on the cognitive context which varies from one person to another; 2 ) the relationship between the perceived meaning and the real world is not such binary opposition, true or false or right or wrong.

To put it in a simple way, I provide several examples as to how the equivalence is not such an absolute judgement, but rather a cognitive-driven judgement that inevitably varies depending on background knowledge or schemata possessed by a reader.

\section{a. The Close-Reading on Colonialism}

Prior to analyzing the equivalence of the addressing term of Tuan in the novel, it is essential to bear in mind that one of contextual use of Tuan in the colonial era is to exhibit the power relation and superiority of the colonialists before the colonized subjects-which in this case refer to Natives. It was also used to maintain the hegemonic tentacles in overall systems, including legal, cultural, language, to name a few. To practically elaborate this, I present this excerpt along with its translation as follows:

\section{Bagaimana pula Tuan Herman Mellema, pemilik seluruh kekayaan melimpah ini? (BM, p. 24)}

\section{And what about Mr. Mellema, owner of all this abundant wealth? (TEM, p. 33)}

This excerpt is the Minke's monologue in describing and questioning the conditions of the Mellema Family, particularly as to how Mr. Mellema looks like since Minke had not yet met with him in person. The way Minke addressed Mr. Mellema, even in his monologue, by using Tuan implies two assumptions: first, he tried to be polite and respected the figure of Mr. Mellema as the host; second, he consciously or unconsciously acknowledged such well-established hegemony in the social strata that there was an unbridgeable gap between the colonists and the colonized subjects. Either of which, these two assumptions demonstrate how such non-reciprocal and 
asymmetrical power relation was indeed the undeniable part of social phenomena during the colonial era. Further, the way how the translator translated this addressing term into Mr. Mellema (thus, literal translation) also implies two interesting assumptions wherein each assumption highly relies on to what extent a reader might grasp the inferred meaning. The first assumption is that by using the honorific term of $M r$., a reader might infer that the translator did not grasp the cultural gap and asymmetrical power relation I mentioned earlier since this vocative term $\mathrm{Mr}$. nowadays undergoes such semantic change (narrowing). It is merely used to address those respectful people without any colonist-colonized or master-slave power relations since it is widely known that slavery has been banished in the Anglo-American culture. However, the second assumption is also quite essential to consider. The way the translator used the vocative term $\mathrm{Mr}$. implies that he was fully aware of such asymmetrical power relation and thus used the term $\mathrm{Mr}$. during the American slavery era to create equal influence upon target readers. In fact, this term was indeed used by a slave to obligately address his/her master (Brown \& Gilman, 1960). In other words, the latter assumption can possibly reject the first one-although, as I frequently mention again and again that it entirely depends on the reader's background knowledge or schemata.

However, once we refer to another excerpt, such in one I will present, the equivalence of the addressing term of Tuan can also indicate the mutual T/V solidarity relation.

"Tamu Annelies juga tamuku," katanya dalam Belanda yang fasih. "Bagaimana aku harus panggil? Tuan? Sinyo? Tapi bukan Indo..." (BM, p.19)

"Annelies's guests are my guests too," she said. Her Dutch was so fluent. "How shall I call you? Sir? Sinyo? But you're not Indo." (TEM, p. 29)

This excerpt describes the conversation between Nyai Ontosoroh and Minke. She showed her discomfort to address Minke, either by using Tuan or Sinyo. It indicates that the addressing term during the colonial era was assuredly of importance to label the social identity. By asking Minke how to address him properly, Nyai Ontosoroh demonstrated her respect upon Minke with whom she had not yet been familiar. Instead of indicating an asymmetrical power relation, she used the term of Tuan to convey her mutual $V$ solidarity upon someone who was in equally respectful position as her (since Minke was acknowledged as an H.B.S. student). Thus, the literal translation used by the translator can be considered equal in both literal and contextual meaning, in that it still fully accommodates the solidarity relation between collocutors.

\section{Stylistic Shift of Addressing Terms}

\section{a. The Fidelity Ambivalence vis-à-vis the Equivalence as a Mediating Attempt}

If we refer to the distribution of translation procedures used, it seems as if the translator was inconsistent in translating the addressing term of Tuan. In a particular situation, he translated it as Mr. or Sir, and in another situation as Tuan or Tuans. The question is whether the translator should consistently select either one of two well-known translation approaches, i.e., ST-based and TT-based translation. In my opinion, due to various context-dependable issues such as in the two previous examples, the translation equivalence should not merely consider whether or not there is a fidelity ambivalence demonstrated by a translator-and consequently leads to the judgement on the translator's consistency. More importantly, the equivalence should be perceived as a mediating attempt carried out by a translator while addressing many contextual issues which inevitably vary from one occasion to another. The most important consideration is that how such equivalence can fully accommodate and transpose the intended influence in the source text into the target text so that the readers in both texts share the equal reception. Besides, the distinct translation variants of the addressing term of Tuan might also appear as the result of the fundamentally different language system. I will give an example regarding the various translator's choices in translating the term of Tuan as the result of the distinct pronoun system between the Indonesian language and the English language.

The following excerpt is the conversation between Mr. Mellema and his son, Maurits Mellema.

"In-si-nyur Maurits Mellema, Tuan Mellema! ... dengarkan Tuan Mellema! Ibuku Mevrouw Amelia Mellema-Hammers, setelah Tuan tinggalkan secara pengecut, 
harus ... Aku dan Mevrouw Mellema-Hammers sudah bertekad tak mengharapkan kedatangan Tuan, Tuan Mellema. Tuan lebih kamianggap telah lenyap ditelan bumi. Kami tak mencari berita di mana Tuan berada." (BM, p. 102)

"En-gin-eer Maurits Mellema, Mr. Mellema! ... Listen, Mr. Mellema. My mother, Mrs. Amelia Mellema-Hammers, after you left in such a cowardly manner, had to work ...I and Mrs. Mellema-Hammers had resolved no longer to hope for your return, Mr. Mellema. As far as we were concerned, you had disappeared, swallowed up by the earth. We sought no reports of your whereabouts." (TEM, p. 96-97)

Before analyzing the addressing term of Tuan in the above excerpt, it is crucial to grasp the stylistic 'tone' of Maurits Mellema as talking to his father, Mr. Mellema, in the source text. This conversation is full of emotional agitation, arrogance, and vengeance yet still delivered in a coldheartedly polite manner, by enacting the repetition of Tuan to address his father. Instead of implying that the term of Tuan is used to indicate Maurits's respect upon his father, the addressing term of Tuan, to some extent, was intentionally used to exhibit arrogance and vengeance towards Mr. Mellema. Regardless, the cold-heartedly polite manner performed by Maurits to mock arrogantly his father cannot be fully transposed into the target text since the translator preferred to use the pronoun you to translate the addressing term of Tuan. Due to this, it can be inferred that the stylistic 'tone' in the target text seems more arrogant and hurtful. However, it seems reasonable for the translator not to repeat the addressing term of $M r$. and rather replaced it with pronoun you since English is not familiar with the repetition of a proper name or the addressing term in this case. Many researches pointed out a similar issue regarding the difficulties in translating the repetition in many languages, for instance, Boase-Beier (2014) quoting Ben-Ari's notion that the avoidance of translating repetition seems to be a predominant norm that can be found in all translated texts. In other words, the interchangeable use of Mr. and you in the target text cannot be used to judge the translator's consistency.

\section{b. Translationese as the Realization of the Translator's Creative Transposition}

This last section investigates the translator's preference to use the calque procedure in translating two addressing terms, namely Tuan-Tuan Totok Peranakan and Tuan Besar Kuasa. Prior to analyzing these two addressing terms, the excerpt containing them is presented as follows:

(1) Sebagai jurubayar pabrik ia akan menjadi orang besar di Tulangan. Pedagang akan membungkuk menghormati. Tuan-tuan Totok dan Peranakan akan memberi tabik dalam Melayu. (BM, p. 81)

As paymaster he would be a big man in Tulangan. Merchants would bow down in respect. The Pure and Mixed-Blood tuans would greet him in Malay. (TEM, p. 7980)

(2) Malah melalvi dukun dan tirakat ia berusaha menggendam Tuan Administratur, Tuan Besar Kuasa, agar sudi datang ke rumah. Juga tak berhasil. (BM, p. 82)

He even went as far as using a dukun magic man and ascetic practices to cast a spell on the tuan administrator, the Tuan Besar Kuasa, the "Great, Powerful Tuan," to come to the house. Also to no avail. (TEM, p. 80)

These two excerpts are the story narrated by Nyai Ontosoroh to her daughter, Annelies. In the excerpt (1), it describes the excessive obsession of Nyai's father, Paiman or Sastrotomo, to get the job promotion as the paymaster. The addressing term of Tuan-tuan used in this excerpt indicates a general reference, not for any particular Pure and Indo-Europeans. In fact, the repetition of this term, according to the Indonesian language system, shows that it was addressed to plural entities. Ergo, it is of logic for translators to calque this into tuans by adapting the term to the English language system - which in this case by adding plural inflection -s on the root Tuan. Meanwhile, in the excerpt (2), the calque of the addressing term of Tuan was combined with the borrowing procedure and thus resulted in the phrase the Tuan Besar Kuasa, the "Great, Powerful Tuan". These two procedures indicate that the translator strived to achieve equivalence by mediating the cultural aspects in two texts (ST and TT). By partially maintaining (calque) the term Tuan and later 
adapting it to the English language system, the translator had endeavored to introduce the cultural concept embodied in the addressing term to the target readers. Fauziah (2014) exerted that this calque is arguably problematic since the original term of Tuan, in the Indonesian language system, remains in question. However, in my argument, the calque is unproblematic as what I have been explained previously that repetition, in the Indonesian language system, certainly indicates plural entities. Besides, she probably has not yet considered that this calque belongs to what Hyde (1993) called 'translationese', representing that the translated text uniquely has their own language (Gellerstam, 1986). To some degree, it also reflects that a translator owns prerogative rights to creatively transpose the perceived meaning from the ST to the TT insofar that it can comprehensively achieve the equivalence.

\section{CLOSING MARKS}

Translating the addressing terms increasingly becomes a significant concern in translation studies for it offers varied challenging issues to be studied through many perspectives, e.g., sociolinguistic, stylistic, contrastive linguistic, to name a few. Specifically, this paper mainly shows how the translation of addressing terms involves a wide range of aspects, such as sociocultural and historical values (including social identity and social strata) and power and solidarity relation. Therefore, it raises a number of noteworthy translation issues, i.e., its equivalence, stylistic shift, and translator's strategies. Through the increasing awareness of 'cultural turn' in translation studies, the concept equivalence is supposedly perceived not as an absolute assessment but as a mediating attempt to accommodate and transpose the inferred or perceived meaning from the ST to the TT as much as possible. Only through this perspective, the translation analysis can transcend beyond the personal judgement upon the translator's preference and shift to the critical elaboration of how myriads of factors influence the translator's attitudes towards the ST.

\section{REFERENCES}

Baker, M. 2018. In Other Words: A Coursebook on Translation. London: Routledge.

Bassnett, S., \& Levere, A. 1990. Translation, History and Culture. London and New York: Pinter.

Boase-Beier, J. 2014. Stylistic Approaches to Translation. London and New York: Routledge.

Braun, F. 1988. Terms of Address: Problems of Patterns and Usage in Various Languages and Cultures. Berlin: Mouten de Gruyter.

Brown, R., \& Gilman, A. 1960. The Pronouns of Power and Solidarity. In T. A. Sebeok (Ed.), Style in Language (pp. 253-76). Cambridge: MIT Press.

Fauliyah, S. 2012. Translation of Address Term in Ketika Cinta Bertasbih II (Indonesian-English Subtitle). Anglicist, Vol. 1, No. 2, pp. 29-35.

Fauziah, A. 2014. An Analysis of Translating the Addressing Terms in Pramoedya Ananta Toer's This Earth of Mankind. Language Horizon, Vol. 2, No. 2, pp. 1-9.

Gellerstam, M. 1986. Translationese in Swedish Novels Translated from Swedish. In L. Wollin, \& H. Lindquist (Eds.), Translation Studies in Scandinavia (pp. 88-95). Lund: CWK Gleerup.

Hyde, G. 1993. The Whorf-Sapir Hypothesis and the Translation Muddle. Translation and Literature, Vol. 2, pp. 4-16.

Lotfollahi, B., \& Dabbaghi, A. 2012. Translation of Terms of Address from English to Persian: Strategies in Focus. Mediterranean Journal of Social Sciences, Vol. 3, No. 3, pp. 329-333.

Malmkjær, K. 2004. Translational Stylistics: Dulcken's Translations of Hans Christian Andersen. Language and Literature, Vol. 13, No. 1, pp. 13-24.

Newmark, P. 1988. A Textbook of Translation. New York: Prentice Hall.

Ngo, T. 2006. Translation of Vietnamese Terms of Address and Reference. Translation Journal, Vol. 10, No. 4 .

Nida, E. 1964a. Toward a Science of Translating. Leiden: E. J. Brill. 
Ardik Ardianto

Shehab, E. 2005. The Translatability of Terms of Address in Najib Mahfouz's Ziqaq Al-Midaq into English. An-Najah Univ. J. Res. (H. Sc.), Vol. 19, No. 1, pp. 315-327.

Taavitsainen, I., Jucker, \& Jucker, A. H. 2003. Diachronic Perspective on Address Term Systems. Philadelphia: John Benjamins North America.

Vinay, J.-P., \& Darbelnet, J. 2004. A Methodology for Translation. In L. Venuti (Ed.), The Translation Studies Reader, 2nd edition (pp. 84-93). London and New York: Routledge.

Williams, J., \& Chesterman, A. 2002. The Map: A Beginner's Guide to Doing Research in Translation Studies. Manchester: St. Jerome Publishing.

Yang, C. 2010. Translation of English and Chinese Addressing Terms from the Cultural Aspect. Journal of Language Teaching and Research, Vol. 1, No. 5, pp. 738-742. 